\title{
Diagnosis and treatment of juvenile myelomonocytic leukemia in Slovak Republic: novel approaches
}

\author{
O. FABRI ${ }^{1,2, *}$, J. HORAKOVA ${ }^{2}$, I. BODOVA ${ }^{2}$, P. SVEC ${ }^{2}$, Z. LALUHOVA STRIEZENCOVA ${ }^{1}$, E. BUBANSKA ${ }^{3}$, M. CERMAK ${ }^{4}$, V. GALISOVA ${ }^{5}$, K. SKALICKA $^{5}$, \\ A. VASKA ${ }^{5}$, D. DOCZYOVA ${ }^{2}$, A. PANIKOVA ${ }^{2}$, T. SYKORA ${ }^{2}$, J. ADAMCAKOVA ${ }^{2}$, A. KOLENOVA ${ }^{2, *}$ \\ ${ }^{1}$ Hematology and Transfusiology Department, National Institute of Children's Diseases and Medical Faculty, Comenius University, Bratislava, \\ Slovakia; ${ }^{2}$ Department of Pediatric Hematology and Oncology, National Institute of Children's Diseases and Medical Faculty, Comenius Uni- \\ versity, Bratislava, Slovakia; ${ }^{3}$ Department of Pediatric Hematology and Oncology, Children's Hospital, Banská Bystrica, Slovakia; ${ }^{4}$ Department \\ of Medical Genetics, National Cancer Institute, Bratislava, Slovakia; ${ }^{5}$ Laboratory of Clinical and Molecular Genetics, Department of Pediatrics, \\ National Institute of Children's Diseases and Medical Faculty, Comenius University, Bratislava, Slovakia
}

${ }^{\star}$ Correspondence: fabri.oksana@gmail.com; sasa.kolenova@gmail.com

Received December 31, 2018 / Accepted February 18, 2019

Juvenile myelomonocytic leukemia (JMML) is a rare, aggressive clonal myeloproliferative disorder of infancy and early childhood caused by oncogenic mutations in genes involved in the Ras pathway. Long-term survival has only been achieved with hematopoietic stem cell transplantation (HSCT), being able to cure more than 50\% patients. To manage the disease before HSCT remains an important issue with constant searching for optimal treatment modalities. According to several retrospective analyses, azacitidine (AZA) induced clinical and molecular responses in patients with relapsed JMML pre-transplant and post-transplant, suggesting its use as a promising "bridging" therapy before HSCT.

In this paper we report our first consecutive cohort of patients with JMML treated at our institution as well as our experience with the diagnosis, novel treatment and management of these patients before the HSCT. We present 6 patients with JMML, harboring different somatic mutations (PTPN11 and NRAS), with distinct clinical features; 3 of them had been treated with AZA $75 \mathrm{mg} / \mathrm{m}^{2}$ i.v. on days 1 to 7 of a 28-day cycle before the HSCT. Response to therapy was evaluated after each cycle in accordance with the International response criteria. One patient had a progression of splenomegaly during the treatment and after three cycles he was urgently transplanted. At the present, he is remaining in complete remission 3 years after HSCT. Two patients showed impressive response following the first cycle of the therapy with a regression of splenomegaly and monocyte count, normalized leukocytes, platelets and absent blasts in peripheral blood. The treatment was well tolerated with no adverse effect recorded.

The clinical activity and favorable toxicity of AZA in JMML provide a rationale for its use as a "bridging" therapy before HSCT. Prospective trials with accompanying translational studies are required to provide further information regarding individual factors that may direct the most appropriate choice of pretransplantation therapy.

Key words: juvenile myelomonocytic leukemia, hypomethylation, azacitidine, hematopoietic stem cell transplantation

Juvenile myelomonocytic leukemia (JMML) is a rare aggressive clonal disorder of infancy and early childhood with an estimated incidence of 1.2 cases per million children per year $[1,2,3]$. According to the WHO classification of tumors of hematopoietic and lymphoid tissues published in 2008 , it is considered a separate bridging disorder between myelodysplastic syndrome (MDS) and myeloproliferative neoplasia and represents $2 \%$ to $3 \%$ of all pediatric hematologic malignancies $[1,4,5]$. The median age at diagnosis is two years, with a male to female ratio of $2: 1[6,7]$.

The disease is characterized by excessive myelomonocytic cell proliferation and granulocyte-macrophage colony- stimulating factor (GM-CSF) hypersensitivity [8]. Clinically, patients generally present with pallor, fever, infection, bruising, lymphadenopathy, marked splenomegaly and hepatomegaly $[1,6,9,10,11]$. Leukocytosis with monocytosis, anemia, thrombocytopenia, elevated $\mathrm{HbF}$ and a low number of circulating myeloid precursor cells are common findings in the peripheral blood (PB) $[1,6,7,9-13]$. Bone marrow (BM) is hypercellular with myeloid hyperplasia, scarce megakaryocytes and less than $20 \%$ of myeloid blasts [5]. The hallmark genetic features of JMML are somatic and/ or germline mutations of Ras pathway genes causing deregulation of signaling within the RAS-RAF-MAPK (mitogen- 
activated protein kinase) signaling pathway that results in its constant and pathological activation $[4,15]$. Molecular aberrations in RAS-pathway have recently been included in the diagnostic criteria of the JMML $[2,5,16]$. Differential diagnosis should include diseases that could mimic JMML: human herpesvirus infections (Epstein-Barr virus (EBV), cytomegalovirus (CMV), human herpes virus (HHV), parvovirus B19, Wiskott-Aldrich syndrome, leukocyteadhesion deficiency, infantile malignant osteopetrosis and hemophagocytic lymphohistiocytosis [17-21]. The clinical course is variable depending on the molecular mutations in RAS signaling pathway, epigenetic aberrations (aberrant DNA methylation) and cytogenetic abnormalities. Age $>2$ years at diagnosis, platelet count $<33 \times 10^{9} / 1$, and levels of $\mathrm{HbF}>10 \%$ have been reported as the main predictors of short survival $[6,22]$. Progression to blast crisis is infrequent and the progression rate reported by different study groups ranges from $9.8 \%$ to $18 \%[23,24]$.

Currently, allogeneic HSCT is the only effective treatment being able to cure more than 50\% of JMML patients. In most cases, JMML is a fatal disease if left untreated. The majority of children succumb to respiratory failure as a result of pulmonary infiltration of leukemic cells 10-12 months after the diagnosis [6]. All children with JMML and NF-1, somatic PTPN-11 mutations, K-RAS mutations, and the vast majority of children with somatic N-RAS mutations should be transplanted as soon as possible after establishing the diagnosis. A watch and wait strategy is advised for children with germline CBL mutations, some somatic NRAS mutations and in Noonan syndrome patients because of reported spontaneous resolution of myeloproliferation. HSCT should be considered if chromosomal aberrations occur or if disease progresses. In our paper we report our first consecutive cohort of patients with JMML who were diagnosed at our institution using molecular genetic analysis of genes of the RAS-RAF-MAPK pathway. We report here our first experience with hypomethylating treatment of JMML patients as "bridging" therapy before the HSCT.

\section{Patients and methods}

Between 2013 and 2018, six children with JMML were diagnosed and treated at the National Institute of Children's Diseases in Bratislava, Slovakia. The diagnosis was made in accordance with the criteria of the International JMML Working Group $[1,13]$. Bone marrow and peripheral blood smears were reviewed by reference investigators of the European Working Group of Myelodysplastic Syndromes in Childhood (EWOG-MDS). Molecular genetic testing of PTPN11, NRAS, KRAS, and CBL genes were studied at the University of Freiburg in the EWOG-MDS center and the Laboratory of Clinical and Molecular Genetics at the National Institute of Children's Diseases (Bratislava, Slovakia). Complete remission (CR) of JMML after therapy was defined if all the following criteria were fulfilled: (i) no evidence of circulating blasts in PB, BM with less than 5\% blasts and trilineage hematological recovery; (ii) absence of chromosome abnormalities and (iii) disappearance of clinical symptoms of JMML, such as organomegaly. Partial remission and progression of the disease were diagnosed in accordance with previously published criteria [25].

\section{Results}

Patients' characteristics at the diagnosis are presented in Table 1. Median age at presentation was 3.5 years (range $0.1-7.0$ ). There was a male predominance with a male to female ratio of 2:1. Splenomegaly at the time of diagnosis was noted in all children with median size of $4.3 \mathrm{~cm}$ under costal margin.

Hematological data. At diagnosis, the mean white blood cell (WBC) was $45.82 \times 10^{9} / 1$ (range 18.24-132.0); 5 patients had WBC less than $50 \times 10^{9} / 1$ with only one child having hyperleukocytosis exceeding $100 \times 10^{9} / 1$. Monocytosis was evident in all cases with mean absolute monocyte count $7.35 \times 10^{9} / 1$. All patients had high $\mathrm{HbF}$ (median $25.67 \%$; range 4.0-69.4) and low PLT (median 61.1\%; range 35.0-92.0). The percentage of blasts in $\mathrm{PB}$ ranged from $1 \%$ to $5 \%$ and in $\mathrm{BM}$ from $3 \%$ to $20 \%$ (Table 1 ).

Chromosomal analyses of BM cells were performed by standard techniques at the national reference laboratory in all patients and confirmed a normal karyotype in 5 children. In one case (patient 3) conventional cytogenetics (G-banding) revealed composite karyotype with 47-49 chromosomes, deletion of long arm of chromosome 6 in region 6q21 (=del(6q21)) and two different marker chromosomes (structurally abnormal chromosomes that cannot be unambiguously identified) each in two copies; she had somatic PTPN11 mutation and shortly after the diagnosis developed a blast crisis. BCR-ABL fusion gene was excluded in all patients (Table 1).

Gene mutation analysis was performed in all patients using Sanger sequencing, a method based on the selective incorporation of chain-terminating dideoxynucleotides performed with ABI PRISM 3100. Three patients were diagnosed with somatic NRAS mutation, two with somatic PTPN11 and one child was diagnosed both with Noonan syndrome and germinal PTPN11 mutation (Table 2).

Treatment. Mean time from diagnosis to HSCT was 5.4 months (range 3.0-10.0). Depending on the clinical situation, time at the diagnosis and availability of a donor, children received different type of treatment to control the disease burden before the HSCT (Table 2). Two children received a combination of mercaptopurine $(6 \mathrm{MP})$ and cytarabine (ARA-C), one child AZA + 6MP, one child AZA + $6 \mathrm{MP}+\mathrm{ARA}-\mathrm{C}$, and in one patient the disease was controlled with AZA single therapy. Four out of 5 patients had a partial remission before the HSCT. Five patients underwent allogeneic HSCT with myeloablative conditioning consisting of busulfan, cyclophosphamide and melphalan (BuCyMel). 
Table 1. Characteristics of the patients at diagnosis.

\begin{tabular}{|c|c|c|c|c|c|c|c|c|c|c|c|c|c|}
\hline Patient & $\begin{array}{l}\text { Year } \\
\text { of } \mathrm{Dg}\end{array}$ & $\begin{array}{l}\text { Sex/Age } \\
\text { (years) }\end{array}$ & $\begin{array}{c}\text { WBC } \\
\left(\times 10^{9} / 1\right)\end{array}$ & $\begin{array}{l}\text { AMoC } \\
\left(\times 10^{9} / 1\right)\end{array}$ & $\begin{array}{c}\text { PB } \\
\text { blasts (\%) }\end{array}$ & $\begin{array}{c}\mathrm{Hb} \\
(\mathrm{g} / \mathrm{dL})\end{array}$ & $\begin{array}{c}\text { PLT } \\
\left(\times 10^{9} / 1\right)\end{array}$ & $\begin{array}{c}\mathrm{HbF} \\
(\%)\end{array}$ & $\begin{array}{c}\text { BM } \\
\text { blasts (\%) }\end{array}$ & Karyotype & Molecular genetics & $\begin{array}{c}\text { Treatment } \\
\text { before } \\
\text { HSCT }\end{array}$ & $\begin{array}{l}\text { Status } \\
\text { before } \\
\text { HSCT }\end{array}$ \\
\hline 1 & 2013 & $\mathrm{~F} / 3.5$ & 40.7 & 7.06 & 5.0 & 5.8 & 55.0 & 4.0 & 4.0 & $46, \mathrm{XX}[20]$ & $\begin{array}{l}\text { NRAS, exon } 2 \text {, } \\
\text { c.35G }>A \text {; [p.G12D], } \\
\text { somatic }\end{array}$ & $\begin{array}{l}\text { ARA-C, } \\
6 \mathrm{MP}\end{array}$ & PR \\
\hline 2 & 2015 & $\mathrm{M} / 3.3$ & 20.8 & 4.1 & 1.0 & 12.3 & 86.0 & 69.4 & 3.0 & $46, \mathrm{XY}[20]$ & $\begin{array}{l}\text { PTPN11, exon 3. c. } 226 \mathrm{G}>\mathrm{C} \text {; } \\
\text { [p.E76Q], } \\
\text { somatic }\end{array}$ & $\begin{array}{c}\text { Aza } 3 \text { cycles, } \\
6 \mathrm{MP}\end{array}$ & PD \\
\hline 3 & 2016 & $\mathrm{~F} / 7.0$ & 18.24 & 8.43 & 3.0 & 5.8 & 63.0 & 4.95 & 20.0 & $\begin{array}{c}47-49, \mathrm{XX}, \\
\operatorname{del}(6 \mathrm{q} 21), \\
+\operatorname{mar} 1,+\operatorname{mar} 2 \times 2 \\
[\mathrm{cp} 20]]\end{array}$ & $\begin{array}{l}\text { NRAS, exon } 2 \text {, } \\
\text { c.38G>A; [p.G13D], } \\
\text { somatic }\end{array}$ & $\begin{array}{l}\text { ARA-C, } \\
6 \mathrm{MP}\end{array}$ & PR \\
\hline 4 & 2017 & $\mathrm{M} / 2.5$ & 20.7 & 2.39 & 4.0 & 8.7 & 35.0 & 16.4 & 7.0 & $46, \mathrm{XY}[20]$ & $\begin{array}{l}\text { PTPN11, exon 3, c.226G >A; [p.E76K], } \\
\text { somatic }\end{array}$ & $\begin{array}{l}\text { Aza } 4 \text { cycles } \\
6 \mathrm{MP}, \text { ARA-C }\end{array}$ & PR \\
\hline 5 & 2018 & $\mathrm{M} / 4.5$ & 132.0 & 12.53 & 1.0 & 8.2 & 36.0 & 29.0 & 3.0 & $46, \mathrm{XY}[20]$ & $\begin{array}{l}\text { NRAS, exon 3, } \\
\text { c.181_182insTGGATACAGATGGTA; } \\
\text { [p.Q61LDTDSK], somatic }\end{array}$ & Aza 3 cycles & PR \\
\hline 6 & 2018 & $\mathrm{M} / 0.1$ & 42.51 & 9.59 & 5.0 & 8.4 & 92.0 & 30.3 & 6.0 & 46, XY[20] & $\begin{array}{l}\text { PTPN11, exon 8, c.923A>G; } \\
\text { [p.N308S], } \\
\text { germinal }\end{array}$ & $6 \mathrm{MP}$ & $\begin{array}{c}\text { Alive } \\
\text { without } \\
\text { HSCT }\end{array}$ \\
\hline
\end{tabular}

Dg- diagnosis; M - male; F - female; WBC- white blood cell count; AMoC - absolute monocyte count; PB- peripheral blood; Hb- hemoglobin; HbF fetal hemoglobin; PLT- platelet count; n/a not applicable; BM- bone marrow; HSCT, hematopoietic stem cell transplantation; PR - partial remission; PD -progressive disease; ARA-C - cytarabine, $40 \mathrm{mg} / \mathrm{m}^{2}$ dose for 5 days; $6 \mathrm{MP}$ - mercaptopurine, $50 \mathrm{mg} / \mathrm{m}^{2}$ dose; Aza - azacitidine, $75 \mathrm{mg} / \mathrm{m}^{2}$ dose for day $1-7$ of a 28 days cycle.

Table 2. Treatment of the patients.

\begin{tabular}{|c|c|c|c|c|c|c|c|c|c|c|c|}
\hline Patient & $\begin{array}{l}\text { Sex/Age } \\
\text { (years) }\end{array}$ & $\begin{array}{l}\text { Year } \\
\text { of Dg }\end{array}$ & Molecular genetics & $\begin{array}{l}\text { Interval } \\
\text { from Dg } \\
\text { to HSCT } \\
\text { (months) }\end{array}$ & $\begin{array}{c}\text { Treatment before } \\
\text { HSCT }\end{array}$ & $\begin{array}{l}\text { Status } \\
\text { before } \\
\text { HSCT }\end{array}$ & $\begin{array}{c}\text { HSCT } \\
\text { conditioning }\end{array}$ & Donor & $\begin{array}{l}\text { Source } \\
\text { of cells }\end{array}$ & $\begin{array}{c}\text { FUP } \\
\text { (years) }\end{array}$ & Status \\
\hline 1 & $\mathrm{~F} / 3.5$ & 2013 & $\begin{array}{l}\text { NRAS, exon } 2 \text {, } \\
\text { c.35G>A; [p.G12D], } \\
\text { somatic }\end{array}$ & 10.0 & ARA-C, 6MP & PR & BuCyMel & HLA 9/10 & $\mathrm{BM}$ & 4.0 & Alive/CR \\
\hline 2 & $\mathrm{M} / 3.3$ & 2015 & $\begin{array}{l}\text { PTPN11, exon 3. c.226G>C; [p.E76Q], } \\
\text { somatic }\end{array}$ & 3.0 & Aza 3 cycles, $6 \mathrm{MP}$ & $\mathrm{PD}$ & BuCyMel & HLA $10 / 10$ & $\mathrm{BM}$ & 3.0 & Alive/CR \\
\hline 3 & $\mathrm{~F} / 7.0$ & 2016 & $\begin{array}{l}\text { NRAS, exon } 2 \text {, } \\
\text { c.38G }>\text { A; [p.G13D], } \\
\text { somatic }\end{array}$ & 4.0 & ARA-C, 6MP & PR & BuCyMel & HLA $10 / 10$ & PBSC & D56+ & Death /TRM \\
\hline 4 & $\mathrm{M} / 2.5$ & 2017 & $\begin{array}{l}\text { PTPN11, exon 3, c.226G>A; [p.E76K], } \\
\text { somatic }\end{array}$ & 6.0 & $\begin{array}{l}\text { Aza } 4 \text { cycles } \\
6 \mathrm{MP}, \text { ARA-C }\end{array}$ & PR & BuCyMel & HLA 9/10 & $\mathrm{BM}$ & 0.5 & Alive/CR \\
\hline 5 & $\mathrm{M} / 4.5$ & 2018 & $\begin{array}{l}\text { NRAS, exon 3, } \\
\text { c.181_182insTGGATACAGATGGTA; } \\
\text { [p.Q61LDTDSK], somatic }\end{array}$ & 4.0 & Aza 3 cycles & $\mathrm{PR}$ & BuCyMel & HLA $10 / 10$ & $\mathrm{BM}$ & 0.3 & Alive/CR \\
\hline 6 & $\mathrm{M} / 0.1$ & 2018 & $\begin{array}{l}\text { PTPN11, exon 8, c.923A >G; } \\
\text { [p.N308S], } \\
\text { germinal }\end{array}$ & $\mathrm{n} / \mathrm{a}$ & $6 \mathrm{MP}$ & $\mathrm{n} / \mathrm{a}$ & $\mathrm{n} / \mathrm{a}$ & $\mathrm{n} / \mathrm{a}$ & $\mathrm{n} / \mathrm{a}$ & $\mathrm{n} / \mathrm{a}$ & Alive \\
\hline
\end{tabular}

Dg- diagnosis; M - male; F - female; PBSC- peripheral blood stem cells; BM- bone marrow; HSCT, haematopoietic stem cell transplantation; PR - partial remission; CR -complete remission; PD - progressive disease; ARA-C - cytarabine, dose $40 \mathrm{mg} / \mathrm{m}^{2}$ for 5 days; $6 \mathrm{MP}$ - mercaptopurine, dose $50 \mathrm{mg} / \mathrm{m}^{2}$; Aza - azacitidine, dose $75 \mathrm{mg} / \mathrm{m}^{2}$ for day 1-7 of a 28 days cycle; n/a not applicable; BuCyMel - Busulfan, Cyclophosphamide, Melphalan; HLA - human leukocyte antigens; FUP - follow-up; TRM - transplant-related mortality.

Four are alive in a complete remission with median followup 1.6 years after HSCT (range $0.3-4.0$ years); one girl with blast crisis at diagnosis died from transplant-related causes on day $56+$ following HSCT. A child with Noonan syndrome and germline mutation was successfully treated with $6 \mathrm{MP}$ alone (Table 3).

\section{Discussion}

The clinical and laboratory features of the patients presented here are in accordance with previously published studies $[4,6,7]$. There was a male predominance, with a male to female rate of $2: 1$. Splenomegaly, lymphadenopathy, 
recurrent infections, bleeding, monocytosis, low blasts percentage in peripheral blood and bone marrow smears as well as mutations in RAS genes were the hallmarks of the disease. According to current studies, approximately $90 \%$ of patients with JMML have mutually exclusive mutations in PTPN11, NF1, NRAS, KRAS and CBL in their leukemic cells $[1,11,14,15,25,26]$. Altogether, $35 \%$ of patients with JMML show somatic mutations in PTPN11, while $20-25 \%$ of them aberrations in the RAS and $15 \%$ in the CBL gene, and $11 \%$ of children with JMML were diagnosed with clinical NF1 [6, 27-29]. Still, it is not clearly understood which (if any) type of Ras pathway mutation determines treatment resistance or disease progression.

In our cohort, three children with somatic NRAS mutations showed completely different disease course requiring different treatment approach before the HSCT (Table 1). All three patients presented with PLT $>33 \times 10^{9} / 1$, had different levels of $\mathrm{HbF}$ (two of them had $\mathrm{HbF}<15 \%$, one $29.0 \%$ ) and showed NRAS mutations involving different codons with different amino acid substitutions. In patient 1 , with NRAS mutation affecting codon 12 who had a favorable PLT count $\left(55.0 \times 10^{9} / 1\right)$ and low $\mathrm{HbF}(4 \%)$, "watch and wait" strategy was applied for almost 10 months until she developed disease progression and was urgently transplanted. To control myeloproliferation we used both $6 \mathrm{MP}$ and low dose ARA-C. Patient 3 with somatic NRAS mutation affecting codon 13 presented at the age of 7 years with extremely aggressive disease, blast crisis and severe respiratory symptoms due to infiltration of the lungs by myelomonocytic cells. At presentation her PLT count was $63.0 \times 10^{9} / 1$ and her $\mathrm{HbF}$ was $4.95 \%$. She required several courses of cytoreduction with $6 \mathrm{MP}$ with good hematological response but progression of splenomegaly and worsening her respiratory symptoms. She was transplanted 4 months later, successfully engrafted but died on D56+ from grade IV GvHD. In patient 5, a novel heterozygous 15bp insertion in NRAS exon 3 c.181_182insTGGATACAGATGGTA; [p.Q61LDTDSK] was identified. Despite borderline platelet count $\left(36.0 \times 10^{9} / 1\right)$ and high $\mathrm{HbF}(29.0 \%)$ at diagnosis, the disease had a relatively stable course. This patient received 3 courses of AZA before the HSCT with good tolerance and no adverse effects. He showed remarkable response straight after the first cycle with lowering WBC and regression of splenomegaly. He was successfully transplanted and has been disease free for 5 months now after HSCT.

It is not known at the time how RAS pathway mutations relate to the heterogeneous disease biology and variable clinical outcome of JMML patients. Some genotype-phenotype correlation studies reported that JMML patients with NRAS mutations have a rather favorable course, including some cases with spontaneous disease regression [30, 31]. Matsuda et al. suggested a mild clinical course for the G12S substitution in N-RAS or K-RAS protein [30]. While confirming that sporadic cases with RAS mutated JMML show long-term survival without treatment, data from the EWOG-MDS did not support a correlation between specific RAS mutation and less aggressive course of the disease implying that children with RAS-mutated JMML who survived without HSCT had normal $\mathrm{HbF}$ and high platelet count [31]. It is advised to use these hematologic parameters to identify those few children with RAS mutations in whom a "watch and wait" strategy can be applied until reliable biological parameters able to predict spontaneous resolution of JMML are identified [2].

Our other two patients had confirmed somatic PTPN11 mutation; germline mutation was established in a baby with Noonan syndrome. Patient 2 had been treated with three cycles of AZA with partial hematological response and progressive splenomegaly. Patient 4 presented with hyperleukocytosis and organomegaly, immediately started on low dose azacitidine with remarkable response after the first cycle. However, before the second cycle of AZA he had progression of leukocytosis up to $142 \times 10^{9} / 1$ requiring additional cytoreduction with $6 \mathrm{MP}$ and ARA-C; his clinical condition was otherwise normal with no progression of organomegaly. After 4 cycles of AZA he was successfully transplanted now remaining in a complete remission with complete donor chimerism 5 months following HSCT.

Table 3. Clinical status and laboratory parameters of patients before cytoreductive Th and at the time of HSCT.

\begin{tabular}{|c|c|c|c|c|c|c|c|c|c|c|c|c|c|}
\hline \multirow[b]{2}{*}{ Patient } & \multirow{2}{*}{$\begin{array}{l}\text { Th before } \\
\text { the HSCT }\end{array}$} & \multicolumn{6}{|c|}{ Before cytoreductive Th } & \multicolumn{6}{|c|}{ At the HSCT (before conditioning) } \\
\hline & & $\begin{array}{r}\text { WBC, } \\
\times 10^{9} / \mathrm{L} \\
\end{array}$ & $\begin{array}{c}\text { PLT, } \\
\times 10^{9} / \mathrm{L} \\
\end{array}$ & $\begin{array}{c}\text { PB blasts, } \\
\%\end{array}$ & $\begin{array}{c}\text { BM blasts, } \\
\%\end{array}$ & $\begin{array}{c}\text { Spleen UCM, } \\
\mathrm{cm}\end{array}$ & $\begin{array}{c}\text { Spleen, USG, } \\
\mathrm{cm}\end{array}$ & $\begin{array}{r}\mathrm{WBC}, \\
\times 10^{9} / \mathrm{L} \\
\end{array}$ & $\begin{array}{c}\text { PLT, } \\
\times 10^{9} / \mathrm{L} \\
\end{array}$ & $\begin{array}{c}\text { PB blasts, } \\
\%\end{array}$ & $\begin{array}{c}\text { BM blasts, } \\
\%\end{array}$ & $\begin{array}{c}\text { Spleen, } \\
\text { UCM, cm }\end{array}$ & $\begin{array}{l}\text { Spleen, } \\
\text { USG, cm }\end{array}$ \\
\hline 1 & ARA-C, 6MP & 40.75 & 55.0 & 5.0 & 4.0 & +2.0 & 8.6 & 12.5 & 27.0 & 0.5 & 19.0 & +3.0 & 12.0 \\
\hline 2 & Aza 3 cycles, $6 \mathrm{MP}$ & 38.5 & 39.0 & 3.0 & 4.0 & +5.0 & 11.0 & 7.5 & 13.0 & 0.0 & 0.5 & +8.0 & 15.0 \\
\hline 3 & ARA-C, $6 \mathrm{MP}$ & 18.24 & 63.0 & 15.0 & 20.0 & +5.0 & 13.0 & 1.81 & 12.0 & 1.0 & 3.0 & +6.0 & 14.0 \\
\hline 4 & $\begin{array}{l}\text { Aza } 4 \text { cycles } \\
\text { 6MP, ARA-C }\end{array}$ & 16.2 & 27.0 & 4.0 & 7.0 & +4.0 & 12.5 & 3.84 & 154.0 & 0.0 & 0.0 & +1.0 & 7.0 \\
\hline 5 & Aza 3 cycles & 131.9 & 36.0 & 1.0 & 3.0 & +5.0 & 12.0 & 38.3 & 39.0 & 0.0 & 0.0 & +2.0 & 9.6 \\
\hline
\end{tabular}

Th - therapy; UCM - under the costal margin; USG - ultrasonography, PB - peripheral blood; BM- bone marrow; HSCT, hematopoietic stem cell transplantation; ARA-C - cytarabine, dose $40 \mathrm{mg} / \mathrm{m}^{2}$ for 5 days; $6 \mathrm{MP}$ - mercaptopurine, dose $50 \mathrm{mg} / \mathrm{m}^{2}$; Aza - azacitidine, dose $75 \mathrm{mg} / \mathrm{m}^{2}$ for day $1-7$ of a 28 days cycle. 
Unlike somatic mutations, patients with germline mutations in PTPN11 gene have been reported to have spontaneous resolution of the disease; the gene have codon substitutions that are largely confined to patients with Noonan syndrome as opposed to the spectrum of somatic lesions that occur de novo in JMML. Our patient with germline PTPN11 mutation has been stable for 11 months now on low dose $6 \mathrm{MP}$. He has been closely followed up with no additional treatment required so far.

Currently, molecular genetics and epigenetic mechanisms are the subject of active research in patients with JMML. Several studies established additional secondary mutations of SETBP1 and JAK3 genes that were observed in high-risk patients and were associated with disease progression and poor clinical outcome [32-34]. Recently, based on gene expression profile of leukemic cells, Bresolin et al. reported nonAML-like and AML-like gene expression profiles among 44 patients with JMML; the AML-like type was associated with dismal prognosis, older age, lower platelet count and high $\mathrm{HbF}$ at diagnosis [35]. According to the study, no correlations were found between gene-expression profile and specific genetic aberrations in the Ras pathway.

In 2011, the first large study on methylation in JMML patients was published that analyzed the methylation status at fourteen candidate loci [36]. It described CpG island hypermethylation of promoter regions in 4 of the 14 investigated genes (BMP4, CALCA, CDKN2B, RARB), and stated it as the strongest adverse prognostic factor in JMML and as a predictor of relapse after allogeneic HSCT [36]. The aberrant methylation was clonal and the authors considered it as a probable initiating event. Several studies have evaluated the DNA hypermethylation status at various genes and its association with the clinical risk in patients with JMML [37-39]. Recently, another large study has been conducted by EWOG-MDS that analyzed the methylome of leukemic cells of 148 children with JMML [40]. Widespread DNA hypermethylation in leukemic cells was noted in a group of patients with highest cumulative incidence of relapse following HSCT, which demonstrated that DNA hypermethylation is associated with activated RAS signaling and is a hallmark of aggressive JMML [40]. Based on a methylome analysis, the authors identified three clinically relevant JMML subgroups with distinct molecular genetic patterns: the high methylation subgroup (HM) included patients with somatic PTPN11 mutations and cases with poor clinical outcome; the intermediate methylation group (IM), encompassing patients with monosomy 7 and somatic KRAS mutations; the low methylation subgroup (LM) included patients with CBL syndrome and Noonan syndrome with MPD, and patients with a somatic NRAS mutation.

JMML is a fatal disease if left untreated. To eliminate the pathological clone, allogeneic HSCT with myeloablative conditioning, including three alkylating agents is recommended and so far, it remains the only curative treatment with potential to cure more than $50 \%$ of patients [2]. The most serious cause of treatment failure is disease recurrence with cumulative incidence reported by some authors to be as high as $35 \%$ [41].

For many decades, cytoreductive therapy with $6 \mathrm{MP}$ at a $50 \mathrm{mg} / \mathrm{m}^{2}$ dose or low dose i.v. cytarabine in a $40 \mathrm{mg} /$ $\mathrm{m}^{2}$ dose for 5 days have been used to control the JMML symptoms before the HSCT [42]. In aggressive cases, high dose fludarabine $30 \mathrm{mg} / \mathrm{m}^{2}$ and cytarabine $2 \mathrm{~g} / \mathrm{m}^{2}$ daily for 5 consecutive days have been adopted by some centers [10] However, neither intensive nor low dose chemotherapy has been demonstrated to improve the outcome of patients with JMML [22].

With an increasing understanding of changes in molecular and epigenetic mechanisms underlying JMML, new potential drugs have come to the healthcare community's attention. AZA is an inhibitor of DNA methyltransferase that has been used for the treatment of MDS. There has been an increasing number of case reports in literature on the use of low-dose AZA in JMML children before the HSCT, indicating good clinical response and even a complete clinical, cytogenetic and/or molecular genetic remission in a certain proportion of patients with JMML $[43,44]$. A phase 2 multicenter clinical trial of AZA has been recently opened in Europe aiming to prospectively evaluate the rate of clinical remission (complete or partial) after 3 cycles of AZA before the HSCT in pediatric patients with newly diagnosed JMML. To control myeloproliferation before HSCT, our three patients (patient 2, 4 and 5; Table 2) received low-dose AZA at a $75 \mathrm{mg} / \mathrm{m}^{2}$ dose on day 1 to 7 of 28 days cycle. Patient 2 and 5 had 3 cycles, patient 4 received 4 cycles. Patient 2 had a progression of splenomegaly while on AZA, and after finishing 3 cycles, he required further treatment with $6 \mathrm{MP}$. He was successfully transplanted, but because of a massive splenomegaly interfering with engraftment, he had undergone splenectomy on day 54+ and now remains disease-free 3 years after HSCT. In contrast, both patients 4 and 5 showed impressive response straight after the first cycle of AZA with regression of leukocytosis, splenomegaly, normalization of PLT and reduction of blasts in PB and BM. At the time of HSCT, both were classified as partial response and were successfully transplanted with no major complications (Table 3).

To date, allogeneic HSCT remains the only curative treatment for JMML. With the advent of novel treatment options, targeting epigenome and hypomethylating agents in JMML are increasingly used as a bridging therapy before the transplant. However, incidence and duration of remission induced by hypomethylating agents before the HSCT and its influence on the overall survival following HSCT remains to be answered in prospective multicenter trials.

Acknowledgements: The authors would like to thank colleagues from the European Working Group of Myelodysplastic Syndromes in Childhood (EWOG-MDS), especially Professor Charlotte Niemeyer for the excellent and fruitful co-operation. 


\section{References}

[1] NIEMEYER CM, KRATZ CP. Paediatric myelodysplastic syndromes and juvenile myelomonocytic leukaemia: molecular classification and treatment options. Br J Haematol 2008; 140: 610-624. https://doi.org/10.1111/j.13652141.2007.06958.x

[2] LOCATELLI F, NIEMEYER CM. How I treat juvenile myelomonocytic leukemia. Blood 2015; 125: 1083-1090. https:// doi.org/10.1182/blood-2014-08-550483

[3] ARICO M, BIONDI A, PUI CH. Juvenile myelomonocytic leukemia. Blood 1997; 90: 479-488.

[4] HASLE H, KERNDRUP G, JACOBSEN BB. Childhood myelodysplastic syndrome in Denmark: incidence and predisposing conditions. Leukemia 1995; 9: 1569-1572.

[5] BAUMANN I, BENNETT JM, NIEMEYER CM, THIELE J, SHANNON K. Juvenile myelomonocytic leukaemia, pp 82-84. In: SH Swerdlow, E. Campo, NL Harris, ES Jaffe, SA Pileri et al. (Eds.). WHO classification of tumours of haematopoietic and lymphoid tissues, $4^{\text {th }}$ Edition. IARC Press, Lyon 2008, p 439. ISBN 978-92-832-2431-0

[6] NIEMEYER CM, ARICO M, BASSO G, BIONDI A, CANTU RAJNOLDI A et al. Chronic myelomonocytic leukemia in childhood: a retrospective analysis of 110 cases. European Working Group on Myelodysplastic Syndromes in Childhood (EWOG-MDS). Blood 1997; 89: 3534-3543.

[7] CASTRO-MALASPINA H, SCHAISON G, PASSE S, PASQUIER A, BERGER R et al. Subacute and chronic myelomonocytic leukemia in children (juvenile CML). Clinical and hematologic observations, and identification of prognostic factors. Cancer 1984; 54: 675-686.

[8] EMANUEL PD, BATES LJ, CASTLEBERRY RP, GUALTIERI RJ, ZUCKERMAN KS. Selective hypersensitivity to granulocyte-macrophage colony-stimulating factor by juvenile chronic myeloid leukemia hematopoietic progenitors. Blood 1991; 77: 925-929.

[9] SAKASHITA K, MATSUDA K, KOIKE K. Diagnosis and treatment of juvenile myelomoncytic leukemia. Pediatr Int 2016; 58: 681-690. https://doi.org/10.1111/ped.13068

[10] NIEMEYER CM, KRATZ C. Juvenile myelomonocytic leukemia. Curr Oncol Rep 2003; 5: 510-515.

[11] LOH ML. Recent advances in the pathogenesis and treatment of juvenile myelomonocytic leukaemia. Br J Haematol 2011; 152: 677-687. https://doi.org/10.1111/j.13652141.2010.08525.x

[12] LOH ML. Childhood myelodysplastic syndrome: focus on the approach to diagnosis and treatment of juvenile myelomonocytic leukemia. Hematology Am Soc Hematol Educ Program 2010; 2010: 357-362. https://doi.org/10.1182/asheducation-2010.1.357

[13] CHAN RJ, COOPER T, KRATZ CP, WEISS B, LOH ML. Juvenile myelomonocytic leukemia: a report from the 2 nd International JMML Symposium. Leuk Res 2009; 33: 355-362. https://doi.org/10.1016/j.leukres.2008.08.022

[14] DE VRIES AC, ZWAAN CM, VAN DEN HEUVELEIBRINK MM. Molecular basis of juvenile myelomonocytic leukemia. Haematologica 2010; 95: 179-182. https://doi. org/10.3324/haematol.2009.016865
[15] NIEMEYER CM. RAS diseases in children. Haematologica 2014; 99: 1653-1662. https://doi.org/10.3324/haematol.2014.114595

[16] DVORAK CC, LOH ML. Juvenile myelomonocytic leukemia: molecular pathogenesis informs current approaches to therapy and hematopoietic cell transplantation. Front Pediatr 2014; 2: 25. https://doi.org/10.3389/fped.2014.00025

[17] KAROW A, BAUMANN I, NIEMEYER CM. Morphologic differential diagnosis of juvenile myelomonocytic leukemia-pitfalls apart from viral infection. J Pediatr Hematol Oncol 2009; 5: 380. https://doi.org/10.1097/ MPH.0b013e31819ed260

[18] YOSHIMI A, KAMACHI Y, IMAI K, WATANABE N, NAKADATE $\mathrm{H}$ et al. Wiskott-Aldrich syndrome presenting with a clinical picture mimicking juvenile myelomonocytic leukaemia. Pediatr Blood Cancer 2013; 60: 836-841. https:// doi.org/10.1002/pbc.24359

[19] MANABE A, T. YOSHIMASU T, EBIHARA Y, YAGASA$\mathrm{KI} \mathrm{H}$, WADA $\mathrm{M}$ et al. Viral infections in juvenile myelomonocytic leukemia: prevalence and clinical implications. J Pediatr Hematol Oncol 2004; 26: 636-641. https://doi. org/10.1097/01.mph.0000140653.50344.5c

[20] UNAL S, CETIN M, KUTLAY NY, ELMAS SA, GUMRUK F et al. Hemophagocytosis associated with leukemia: a striking association with juvenile myelomonocytic leukemia. Ann Hematol 2010; 89: 359-364. https://doi.org/10.1007/s00277009-0837-0

[21] HOYOUX C, DRESSE MF, FORGET P, PIETTE C, RAUSIN $\mathrm{L}$ et al. Osteopetrosis mimicking juvenile myelomonocytic leukemia. Pediatr Int 2014; 56: 779-782. https://doi. org/10.1111/ped.12342

[22] PASSMORE SJ, HANN IM, STILLER CA, RAMANI P, SWANSBURY GJ et al. Pediatric myelodysplasia: a study of 68 children and a new prognostic scoring system. Blood 1995; 85: 1742-1750.

[23] HONDA Y, TSUCHIDA M, ZAIKE Y, MASUNAGA A, YOSHIMI A et al. Clinical characteristics of 15 children with juvenile myelomonocytic leukaemia who developed blast crisis: MDS Committee of Japanese Society of Paediatric Haematology/Oncology. Br J Haematol 2014; 165: 682-687. https://doi.org/10.1111/bjh.12796

[24] LUNA-FINEMAN S, SHANNON KM, ATWATER SK, DAVIS J, MASTERSON M et al. Myelodysplastic and myeloproliferative disorders of childhood: a study of 167 patients. Blood 1999; 93: 459-466.

[25] NIEMEYER CM, LOH ML, CSEH A, COOPER T, DVOR$\mathrm{AK} C \mathrm{C}$ et al. Criteria for evaluating response and outcome in clinical trials for children with juvenile myelomonocytic leukemia. Haematologica 2015; 100: 17-22. https://doi. org/10.3324/haematol.2014.109892

[26] CHANG TY, DVORAK CC, LOH ML. Bedside to bench in juvenile myelomonocytic leukemia: insights into leukemogenesis from a rare pediatric leukemia. Blood 2014; 124: 2487-2497. https://doi.org/10.1182/blood-2014-03-300319

[27] TARTAGLIA M, NIEMEYER CM, FRAGALE A, SONG X, BUECHNER J et al. Somatic mutations in PTPN11 in juvenile myelomonocytic leukemia, myelodysplastic syndromes and acute myeloid leukemia. Nat Genet 2003; 34: 148-150. https://doi.org/10.1038/ng1156 
[28] MIYAUCHI J, ASADA M, SASAKI M, TSUNEMATSU Y, KOJIMA $S$ et al. Mutations of the N-ras gene in juvenile chronic myelogenous leukemia. Blood 1994; 83: 2248-2254.

[29] FLOTHO C, VALCAMONICA S, MACH-PASCUAL S, SCHMAHL G, CORRAL L et al. RAS mutations and clonality analysis in children with juvenile myelomonocytic leukemia (JMML). Leukemia 1999; 13: 32-37.

[30] MATSUDA K, SHIMADA A, YOSHIDA N, OGAWA A, WATANABE A et al. Spontaneous improvement of hematologic abnormalities in patients having juvenile myelomonocytic leukemia with specific RAS mutations. Blood 2007; 109: 5477-5480. https://doi.org/10.1182/blood-2006-09-046649

[31] FLOTHO C, KRATZ CP, BERGSTRASSER E, HASLE H, STARY J et al. Genotype-phenotype correlation in cases of juvenile myelomonocytic leukemia with clonal RAS mutations. Blood 2008; 111: 966-967. https://doi.org/10.1182/ blood-2007-09-111831

[32] SAKAGUCHI H, OKUNO Y, MURAMATSU H, YOSHIDA $\mathrm{K}$, SHIRAISHI Y et al. Exome sequencing identifies secondary mutations of SETBP1 and JAK3 in juvenile myelomonocytic leukemia. Nat Genet 2013; 45: 937-941. https://doi. org/10.1038/ng.2698

[33] STIEGLITZ E, TAYLOR-WEINER AN, CHANG TY, GELSTON LC, WANG YD et al. The genomic landscape of juvenile myelomonocytic leukemia. Nat Genet 2015; 47: 1326-1333. https://doi.org/10.1038/ng.3400

[34] CAYE A, STRULLU M, GUIDEZ F, CASSINAT B, GAZAL S et al. Juvenile myelomonocytic leukemia displays mutations in components of the RAS pathway and the PRC2 network. Nat Genet 2015; 47: 1334-1340. https://doi.org/10.1038/ ng.3420

[35] BRESOLIN S, ZECCA M, FLOTHO K, TRENTIN L, ZANGRANDO A et al. Gene expression-based classification as an independent predictor of clinical outcome in juvenile myelomonocytic leukemia. J Clin Oncol 2010; 28: 1919-1927. https://doi.org/10.1200/JCO.2009.24.4426

[36] OLK-BATZ C, POETSCH AR, NOLLKE P, CLAUS R, ZUCKNICK $\mathrm{M}$ et al. Aberrant DNA methylation characterizes juvenile myelomonocytic leukemia (JMML) with poor outcome. Blood 2011; 117: 4871-4880. https://doi. org/10.1182/blood-2010-08-298968
[37] HASEGAWA D, MANABE A, KUBOTA T, KAWASAKI H, HIROSE I et al. Methylation status of the p15 and p16 genes in paediatric myelodysplastic syndrome and juvenile myelomonocytic leukaemia. Br J Haematol 2005; 128: 805-812. https://doi.org/10.1111/j.1365-2141.2005.05392.x

[38] POETSCH AR, LIPKA DB, WITTE T, CLAUS R, NOLLKE $\mathrm{P}$ et al. RASA4 undergoes DNA hypermethylation in resistant juvenile myelomonocytic leukemia. Epigenetics 2014; 9: 1252-1260. https://doi.org/10.4161/epi.29941

[39] SAKAGUCHI H, MURAMATSU H, OKUNO Y, MAKISHI$\mathrm{MA} \mathrm{H}, \mathrm{XU} \mathrm{Y}$ et al. Aberrant DNA methylation is associated with a poor outcome in juvenile myelomonocytic leukemia. PLoS One 2015; 10: e0145394. https://doi.org/10.1371/journal.pone.0145394

[40] LIPKA DB, WITTE T, TOTH R, YANG J, WIESENFARTH $\mathrm{M}$ et al. RAS-pathway mutation patterns define epigenetic subclasses in juvenile myelomonocytic leukemia. Nat Commun 2017; 8: 2126. https://doi.org/10.1038/s41467-01702177-w

[41] LOCATELLI F, NOLLKE P, ZECCA M, KORTHOF E, LANINO E et al. Hematopoietic stem cell transplantation (HSCT) in children with juvenile myelomonocytic leukemia (JMML): results of the EWOG-MDS/EBMT trial. Blood 2005; 105: 410-441. https://doi.org/10.1182/blood-2004-05-1944

[42] BERGSTRAESSER E, HASLE H, ROGGE T, FISCHER A, ZIMMERMANN $\mathrm{M}$ et al. Non-hematopoietic stem cell transplantation treatment of juvenile myelomonocytic leukemia: a retrospective analysis and definition of response criteria. Pediatr Blood Cancer 2007; 49: 629-633. https://doi. org/10.1002/pbc. 21038

[43] FURLAN I, BATZ C, FLOTHO C, MOHR B, LUBBERT $\mathrm{M}$ et al. Intriguing response to azacitidine in a patient with juvenile myelomonocytic leukemia and monosomy 7. Blood 2009; 113: 2867-2868. https://doi.org/10.1182/ blood-2008-12-195693

[44] CSEH A, NIEMEYER CM, YOSHIMI A, DWORZAK M, HASLE $\mathrm{H}$ et al. Bridging to transplant with azacitidine in juvenile myelomonocytic leukemia: a retrospective analysis of the EWOG-MDS study group. Blood 2015; 125: 2311-2313. https://doi.org/10.1182/blood-2015-01-619734 